\title{
sciendo
}

CIVIL AND ENVIRONMENTAL ENGINEERING REPORTS

E-ISSN 2450-8594

CEER 2018; 28 (3): 030-049

DOI: $10.2478 /$ ceer-2018-0033

Original Research Article

\section{DAMAGE DETECTION OF STEEL-CONCRETE COMPOSITE BEAM}

\author{
Maciej SZUMIGAŁA ${ }^{1}$, Agnieszka PEŁKA-SAWENKO ${ }^{2}$ \\ Tomasz WRÓBLEWSKI ${ }^{2}$, Małgorzata ABRAMOWICZ ${ }^{2}$ \\ ${ }^{1}$ Poznan University of Technology, Poznan, Poland \\ ${ }^{2}$ West Pomeranian University of Technology of Szczecin, Szczecin, Poland
}

\begin{abstract}
The paper presents analysis results of steel-concrete composite beams, identification and attempts to detect damage introduced in a discrete model. Analysis of damage detection was conducted using DDL (Damage, Detection, Localization), our own original algorithm. Changes of dynamic and static parameters of the model were analysed in damage detection. Discrete wavelet transform was used for damage localization in the model. Prior to ultimate analysis, two-tier identification of discrete model parameters based on experimental data was made. In identification procedure, computational software (Python, Abaqus, Matlab) was connected in automated optimization loops. Results positively verified the original DDL algorithm for damage detection in steel-concrete composite beams, which enables further analysis using experimental data.
\end{abstract}

Keywords: steel-concrete composite beams, damage, detection, localization, Python, Abaqus, Matlab

\footnotetext{
${ }^{1}$ Corresponding author: Poznan University of Technology, Faculty of Civil and Environmental Engineering, Institute of Structural Engineering, Piotrowo st 5, 60-965 Poznań, Poland, e-mail: maciej.szumigala@put.poznan.pl, tel.+48616652401

${ }^{2}$ Corresponding author: West Pomeranian University of Technology of Szczecin, Faculty of Civil Engineering And Architecture, Piastow st 50, 70-311 Szczecin, Poland, aps@zut.edu.pl, wroblewski@zut.edu.pl
} 


\section{INTRODUCTION}

Steel-concrete composite beams are very often used as main carrying girders of public utility and industrial facilities, road bridges and pedestrian crossings. Owing to the functions composite beams play, special attention should be paid to their operation and technical condition. It is often required to detect damage in an already existing structure. It is common, currently, to constantly monitor the condition of civil engineering structures, particularly in case of newly built structures of key importance for the industry or tourism (e.g. turbine foundations, bridges). Structural health monitoring (SHM) of engineering structures has been discussed in many published papers. It is a system able to control, measure and analyze the initial signal, which is the response of the structure, to signal all irregularities that may provide evidence for the presence of damage. If damage in the structure can be detected early, it can quickly be repaired, which can extend the life-time of the structure. According to [1], SHM is a cross-functional branch which combines elements of mechanics, electronics, IT and materials engineering. SHM should provide data about damage in an element, damage localization, about the degree of damage and prognosis about the time the damaged facility can be used for [2]. Data provided by SHM should be accompanied by information about the structure and history of its use. NonDestructive Testing (NDT) and SHM are based on non-destructive examination methods. NDT relies on periodic examination of the facility in its sensitive points. Both NDT and SHM analyze the initial signal usually based on modal analysis and less often on static analysis.

There exists an extensive body of scientific achievements and detection methods linked to SHM [3-9] and it would be difficult to mention them all. A comprehensive review of the literature and research methods was presented elsewhere [8]. The present paper discusses some methods of damage detection based on wavelet transform analysis and model tuning methods.

Wavelet transform (WT) is used to process and analyze non-stationary signals that provide time-frequency data. 1D, 2D and 3D graphic signals can be processed with it. It is used in analysis of radar and sonar signals, modern medical equipment and in structural health monitoring (SHM) of engineering facilities [10-12].

"Wavelets" are characterized by finite length, limited period, irregular shape and the average value of zero. The above mentioned characteristics show that wavelet transform is particularly useful for analyzing signals and functions, highlighting special points and nonlinearity of the input signal. It can be used for damage detection of civil engineering structures, including steel-concrete composite beams with their use as elements of bridges or composite floors.

As regards composite beams [13], a variety of problems were discussed, including beam deflection with partial or full shear connection [14], reinforcement of 
composite beams using CFRP polymer [15], analysis of aluminium-concrete composite beams [16], analysis of a variety of reinforcement types [17] and many more. SHM problems are still being developed and necessarily so. This paper continues my earlier work and focuses on damage identification and diagnostics in steel-concrete composite beams.

\section{ANALYSIS FUNDAMENTALS}

Wavelet transform can be divided into discrete (DWT) and continuous (CWT) transforms. In wavelet transform, the signal undergoes dilation or translation.

$$
L_{f(a, b)}=\int_{-\infty}^{\infty} f(u) \cdot \psi_{(a, b)}(u) d u
$$

where $\mathrm{f}(\mathrm{u})=$ analyzed signal, $\mathrm{a}=$ dilation parameter, which defines the length of examined signal; $b=$ wavelet translation in time domain, the product of scale coefficient (a) to frequency $(\omega) ; \psi(a, b)=$ mother wavelet.

The present paper discusses DWT (discrete wavelet transform). DWT is based on Mallat algorithm. Contrary to CWT where the signal is analyzed in depth, DWT aims at minimizing the amount of data necessary to represent the signal (decomposition). It is achieved using two filters of high and low frequency. When signal $f(t)$ passes the filters, it is divided into a detailed and approximating parts, referred to as approximation $\left(a_{k}\right)$ and detail $\left(d_{j, k}\right)$.

$$
f(t)=\sum_{k=-\infty}^{\infty} a_{k} \cdot \varphi_{k}(t)+\sum_{j=0}^{\infty} \sum_{k=-\infty}^{\infty} d_{j, k} \cdot \psi_{j, k}(t)
$$

Approximations $\left(a_{k}\right)$ are high-scale and low-frequency elements of the signal. Details $\left(d_{j, k}\right)$ are low-scale and high-frequency signal components. Approximation detail is crucial in damage diagnostics. Further processing of the signal gives more general signal data. What is important is that during decomposition it is possible to detect even small anomalies in the signal, revealing disturbances in system response, which may be evidence of local damage.

The fundamental equation of motion can be given by:

$$
\mathrm{M} \cdot \ddot{q}+\mathrm{C} \cdot \dot{q}+\mathrm{K} \cdot q=\mathrm{P}
$$

where: $\mathrm{M}=$ mass matrix, $\mathrm{K}=$ stiffness matrix, $\mathrm{C}=$ damping matrix, $\mathrm{P}=$ vector of model bias, $\ddot{q}, \dot{q}, q=$ respectively vectors of accelerations, velocities and displacements. 
The eigenvalue problem can be solved by neglecting damping. Thus, after simplifying Equation (3), we receive:

$$
\mathrm{M} \cdot \ddot{q}+\mathrm{K} \cdot q=0
$$

For further analysis, Rayleigh damping was considered. Rayleigh damping consists of mass and stiffness damping matrices, given in its general form by:

$$
\mathrm{C}=\alpha \cdot \mathrm{M}+\beta \cdot \mathrm{K}
$$

where $\alpha=$ damping coefficient, expressed in (t-1) units, which accounts for external damping (it results from friction on supports, friction in bearings, weather conditions, etc.), $\beta=$ damping coefficient, expressed in ( $\mathrm{t}$ ) units, results from viscosity of the structural material.

The dimensionless damping coefficient can be given by:

$$
\gamma=\frac{\alpha}{\omega}+\beta \cdot \omega
$$

where: $\omega=$ frequency of natural vibration.

\section{COMPOSITE BEAM MODEL}

The steel-concrete composite beams were $3.2 \mathrm{~m}$ in length and consisted of a IPE 160 steel I-beam, a $600 \times 600 \mathrm{~mm}$ concrete slab and steel bolts arranged in pairs, every $n=150 \mathrm{~mm}$ along the beam, used as the connection. The slab was made of $\mathrm{C} 30 / 37$ concrete and the I-section was made of S235 steel. The experimental setup was described more in-depth elsewhere [18].
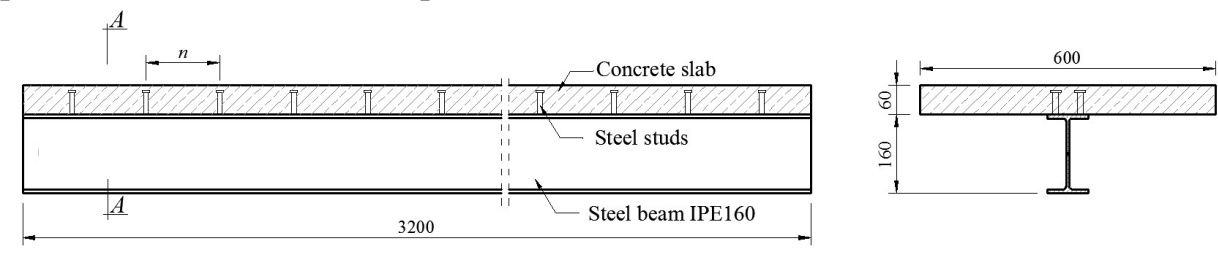

Fig. 1. Steel-concrete composite beam

A discrete model was defined in Abaqus environment as a spatial system. Computational simulation was done on the correlation between results and computation time relative to different modeling of successive components of the composite beam and relative to their different use. The ultimate model combines volume (concrete slab), shell (steel section) and beam elements (steel bolts). A scheme of the computational model is presented in Fig. 2. 


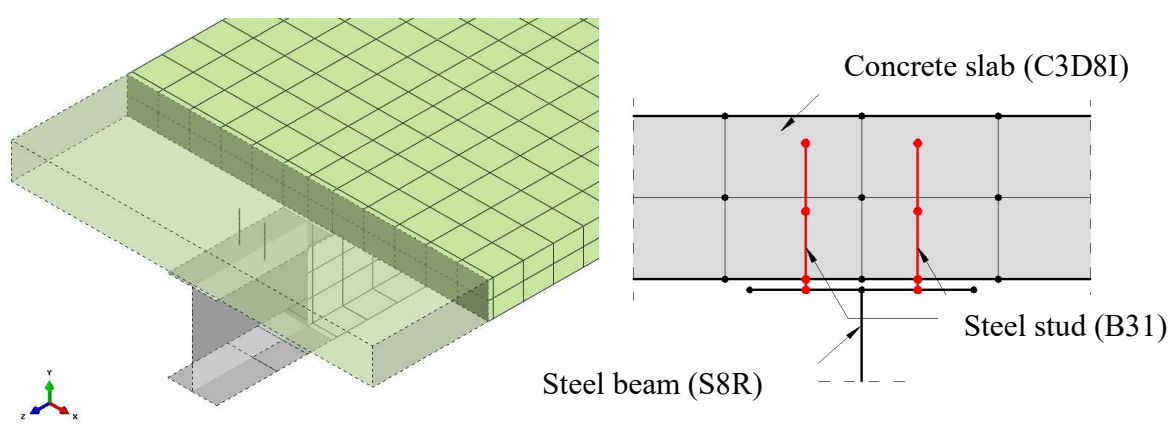

Fig. 2. A model of the composite beams

\section{IDENTIFICATION OF THE DISCRETE MODEL}

\subsection{Identification algorithm of composite beams}

The tuning of computational models is an essential stage in validation $[19,20]$ of discrete models. It is the calibration of selected parameters of a model so that results of numerical experiment overlap those of computational model. Calibration of a discrete model enables further analysis in which preliminary estimation of the system's behavior based on the discrete model can be made. Most parameters of the steel-concrete composite beams was determined based on beam inventory and material data.

Identification was divided into two stages: first, tuning was based on the simplified equation of motion (2.4), second, tuning was based on Equation (2.3). The mass matrix was determined at the level of material definition, based on mass measurements of beam models. The stiffness matrix was determined on the basis of the first stage of identification. The vector of four decision variables can be given by

$$
x_{I}=\left[\mathrm{E}_{\mathrm{d}}, \mathrm{E}_{\mathrm{c}}, \mathrm{K}_{\mathrm{h}}, \mathrm{K}_{\mathrm{v}}\right]
$$

where: $E_{d}, E_{c}=$ substitute longitudinal modulus of elasticity of concrete slab accounting for the effect of longitudinal reinforcement used successively i) dynamical $[\mathrm{Pa}]$ ii) static-shear $[\mathrm{Pa}], \mathrm{K}_{\mathrm{v}}=$ substitute stiffness of connection in normal direction to connection plane, $\mathrm{K}_{\mathrm{h}}=$ substitute stiffness of connection in tangent direction to connection plane. Changes were introduced into the model based on changes in bolt parameters which modified stiffness of beam element, i.e. EA, EJ.

The criterion of stage one analysis was the best fit of the first five frequencies of flexural vibrations (Gv) and fundamental first axial (O) vibration forms for dynamic analysis and the best fit of deflection values $\left(\mathrm{u}_{i}\right)$ for static analysis, hence 


$$
S_{I}=w_{I D} \cdot\left(\sum_{\mathrm{i}_{1}}^{5}\left(\frac{\mathrm{f}_{\mathrm{i}_{-} \text {flex }}^{\text {exp }}-\mathrm{f}_{\mathrm{i}_{-} \text {flex }}^{\text {com }}}{\mathrm{f}_{\mathrm{i}_{-} \text {flex }}^{\text {exp }}}\right)^{2}+\left(\frac{\mathrm{f}_{1-\text { long }}^{\text {exp }}-\mathrm{f}_{1_{-} \text {long }}^{\text {com }}}{\mathrm{f}_{1_{-} \text {long }}^{\text {exp }}}\right)^{2}\right)+w_{I S} \cdot\left(\sum_{\mathrm{i}_{i}=1}^{3}\left(\frac{\mathrm{u}_{\mathrm{i}}^{\text {exp }}-\mathrm{u}_{\mathrm{i}}^{\text {com }}}{\mathrm{u}_{\mathrm{i}}^{\exp }}\right)^{2}\right)
$$

where: $f_{i \_f l e x}=$ flexural vibration, $f_{1}$ long $=$ fundamental axial vibration, $u_{i}=$ beam deflection, $\exp =$ experimental data, $c o m=$ results obtained from discrete model, $\mathrm{w}_{\mathrm{ID}}=$ weight coefficient for dynamic calculations was taken at $0.7, \mathrm{w}_{\mathrm{IS}}=$ weight coefficient for static calculations was taken at 0.3 .

In the second stage, Rayleigh damping coefficients were determined, based on FRF fit with experimental results. The vector of decision variables $\mathrm{x}_{\mathrm{II}}$ can be written

$$
x_{I I}=\left[\beta_{\text {st }}, \alpha_{\text {st }}, \beta_{\text {bet }}, \alpha_{\text {bet }}, \beta_{\text {zesp }}, \alpha_{\text {zesp }}\right]
$$

where: $\alpha=$ external damping coefficient $(\mathrm{t}-1), \alpha=$ internal damping coefficient $(\mathrm{t})$, indices bet $=$ concrete slab, $\mathrm{st}=$ steel beam, zesp $=$ connection .

Frequency Response Function (FRF) of the model was determined using steadystate dynamic analysis (SSD), which analyzes linear response of a structure to harmonic excitation. The Direct method was used in SSD analysis.

The method can be used to independently determine damping parameters for successive elements of concrete slab, steel section or connection. The damping coefficient was ultimately determined based on transformed Equation (2.6). Boundary conditions and excitation were the same as those in the experiment. Excitation was applied in the vicinity of point 2 in vertical direction, Figure 3. Analysis of the excitation caused excitation of vertical flexural vibrations, which will be analyzed in further calculations. At this point of analysis, response of the model was measured in the middle points of the concrete slab and the steel section.

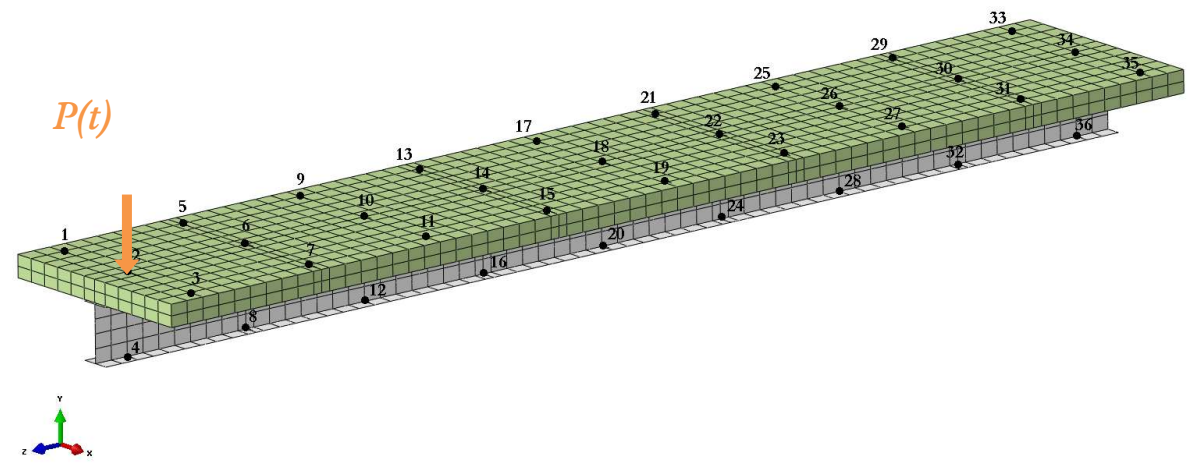

Fig. 3. Measurement points and schematic of discrete model excitation 
The ultimate criterion of stage two identification was the best fit of three amplitudes of flexural vibrations;

$$
S_{I I}=\sum_{\mathrm{i}=1}^{\mathrm{n}} \mathrm{w}_{\mathrm{IIj}} \cdot\left(\frac{\mathrm{FRF}_{\mathrm{i}, \text { mmp }}^{\mathrm{num}}-\mathrm{FRF}_{\mathrm{i}, \text { amp }}^{\mathrm{exp}}}{\mathrm{FRF}_{\mathrm{i}, \text { amp }}^{\mathrm{exp}}}\right)^{2}
$$

where: $F R F_{i \text { amp }}=$ frequency amplitude for the first three frequencies of flexural vibrations, $w_{I I, i}=$ weight vector relative to frequency with successive values of $0.6,0.3,0.1$.

An original optimization program was defined. It combines Python, Matlab and Abaqus environments into calculation loops. Indices $S_{I}$ and $S_{I I}$ were iteratively minimized by the introduction of decision variables $\mathrm{x}_{\mathrm{I}}$ or $\mathrm{x}_{\mathrm{II}}$ (depending on identification stage) into the model. At the first stage, dynamic (ID) and static (IS) parameters were calculated twice each time. At the second stage, calculation was conducted using SSD computational module. In both cases, if minimum conditions were met the program would send new decision variables and the model was recalculated. When the function reached its minimum (in order of E-4), second stage calculation would begin (for optimization process of stage one) or calculation would be finished (for stage two). A schematic of identification is presented in Figure 4.

a)

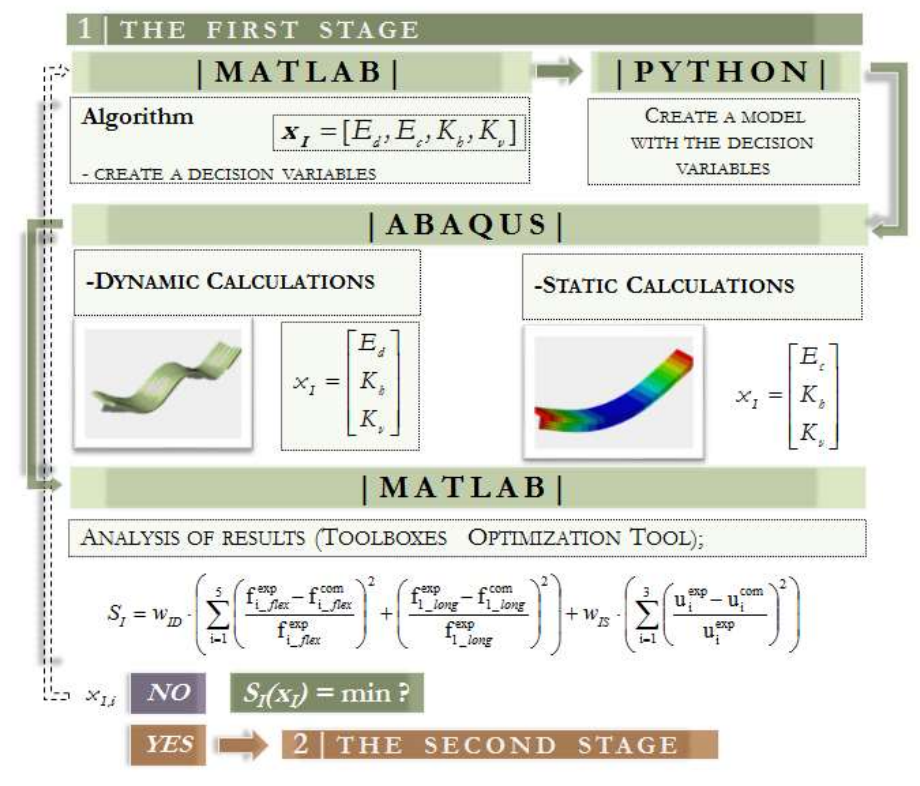


b)

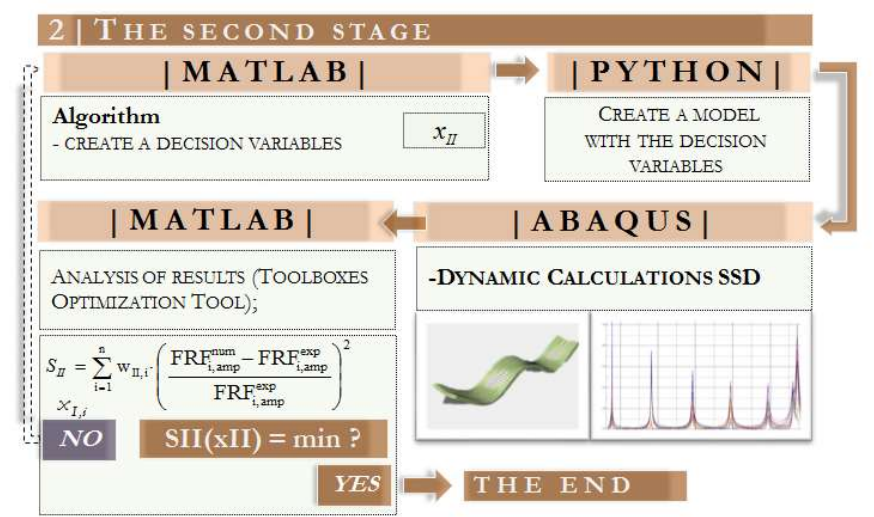

Fig. 4. Identification: a) first stage, b) second stage

\subsection{Identification results for composite beams}

The results of first stage identification for dynamic analysis are presented in Table 1. It compares frequencies of natural vibrations obtained in the experiment with results from the discrete model. In static analysis, beam deflection values for three points were compared. Table 2 shows the results. Table 3 shows vectors of decision variables. Figure 5 shows graphs of selected forms of natural vibrations determined for points on the middle plane of the concrete slab.

Tables 4 and 5 present the results of second stage of identification, i.e. comparison of amplitude values for the first three flexural forms. Figure 6 shows graphs in FRF logarithmic scale for selected measurement points. The values of the ultimate identification criterion of successive stages are presented in Table 6.

Table 1. Identification results of dynamic parameters

$\begin{array}{llll}\text { Form of } & f_{i, \exp } & f_{i, \text { num }} & \Delta f_{i} \\ \text { vibrations } & \mathrm{Hz} & \mathrm{Hz} & \% \\ 1 \mathrm{Gv} & 77.20 & 77.13 & 0.09 \\ 2 \mathrm{Gv} & 178.05 & 178.97 & 0.52 \\ 3 \mathrm{Gv} & 283.14 & 286.68 & 1.25 \\ 4 \mathrm{Gv} & 386.14 & 389.44 & 0.85 \\ 5 \mathrm{Gv} & 493.07 & 491.68 & 0.28 \\ 1 \mathrm{O} & 632.15 & 631.41 & 0.12\end{array}$

Table 2. Identification results of static parameters

$\begin{array}{llll}\text { Measuring } & u_{i, \exp } & u_{i, \text { num }} & \Delta u_{i} \\ \text { point } & \mathrm{Hz} & \mathrm{Hz} & \% \\ \text { p1 } & 2.98 & 2.96 & 0.41 \\ \text { p2 } & 3.33 & 3.38 & 1.5 \\ \text { p3 } & 2.98 & 2.95 & 1.1\end{array}$


Table 3. Results of first stage identification

$\begin{array}{llll}\mathrm{E}_{\mathrm{d}} & \mathrm{E}_{\mathrm{c}} & \mathrm{EA} & \mathrm{EJ} \\ \mathrm{Pa} & \mathrm{Pa} & \mathrm{N} & \mathrm{Nm}^{2} \\ 34.41 \mathrm{e}+9 & 23.58 \mathrm{e}+9 & 7.89 \mathrm{e}+012 & 2.36 \mathrm{e}+12\end{array}$

a)

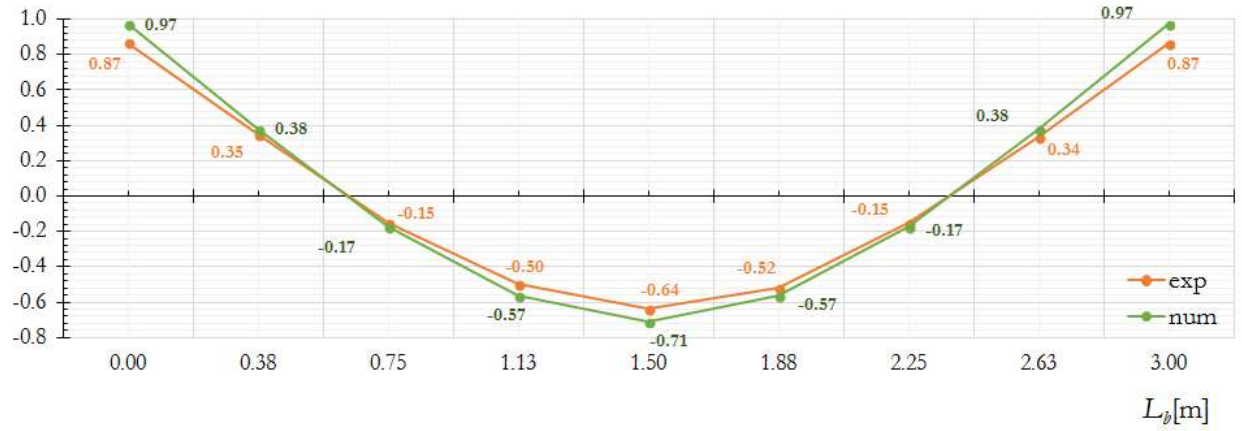

b)

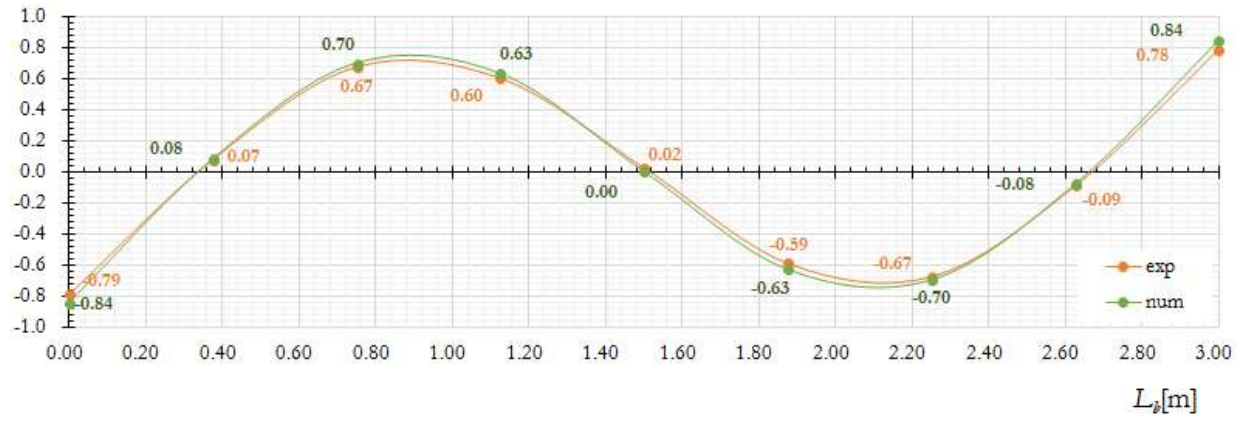

c)

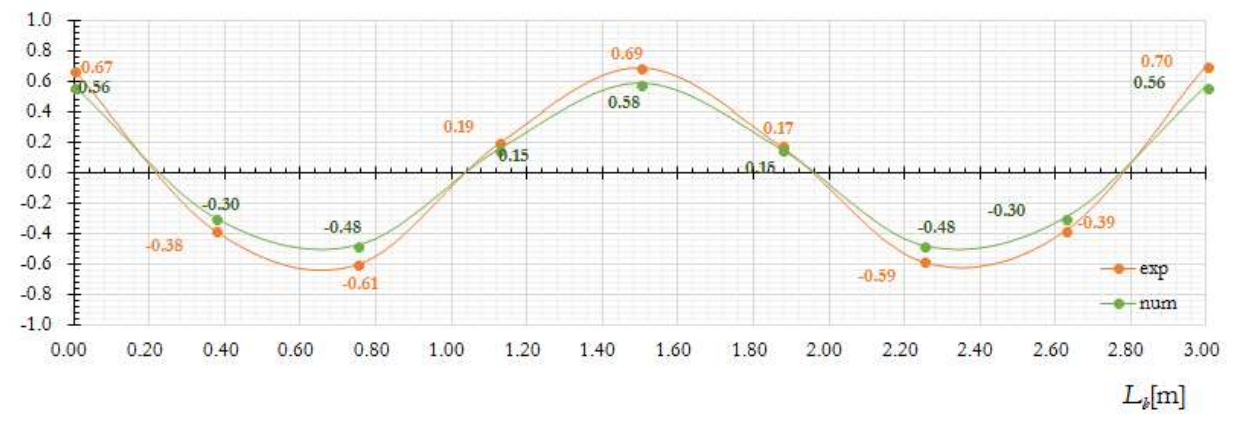

Fig. 5. Graphs of the first three forms of flexural vibrations 
Table 4. FRF identification results

$\begin{array}{llll}\text { No. } & \mathrm{a}_{\mathrm{i}, \exp } & \mathrm{a}_{\mathrm{i}, \text { num }} & \Delta \mathrm{f}_{\mathrm{i}} \\ & \mathrm{m} / \mathrm{s}^{2} / \mathrm{N} & \mathrm{m} / \mathrm{s}^{2} / \mathrm{N} & \% \\ 1 . & 1.26 & 1.26 & 0.7 \\ 2 . & 0.57 & 0.58 & 1.5 \\ 3 . & 0.34 & 0.34 & 2.6\end{array}$

Table 5. Identification results of damping parameters

$\begin{array}{llll}\text { No. } & \gamma_{\text {st }} & \gamma_{\text {bet }} & \gamma_{\text {zesp }} \\ & - & - & - \\ 1 . & 1.75 \mathrm{E}-02 & 1.19 \mathrm{E}-02 & 7.91 \mathrm{E}-03 \\ 2 . & 9.60 \mathrm{E}-03 & 5.27 \mathrm{E}-03 & 4.88 \mathrm{E}-03 \\ 3 . & 8.44 \mathrm{E}-03 & 3.47 \mathrm{E}-03 & 4.81 \mathrm{E}-03 \\ 4 . & 8.71 \mathrm{E}-03 & 2.74 \mathrm{E}-03 & 5.35 \mathrm{E}-03 \\ 5 & 9.47 \mathrm{E}-03 & 2.36 \mathrm{E}-03 & 6.08 \mathrm{E}-03\end{array}$

a)

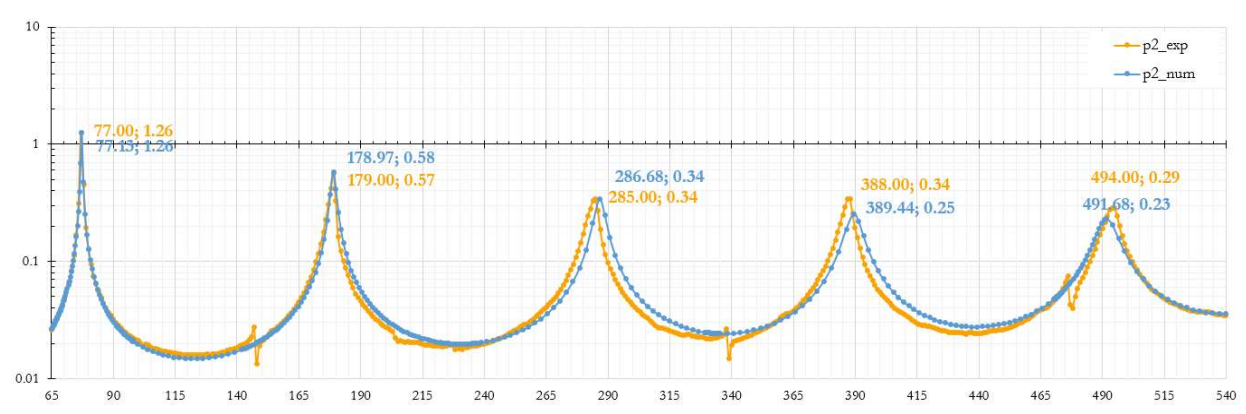

b)

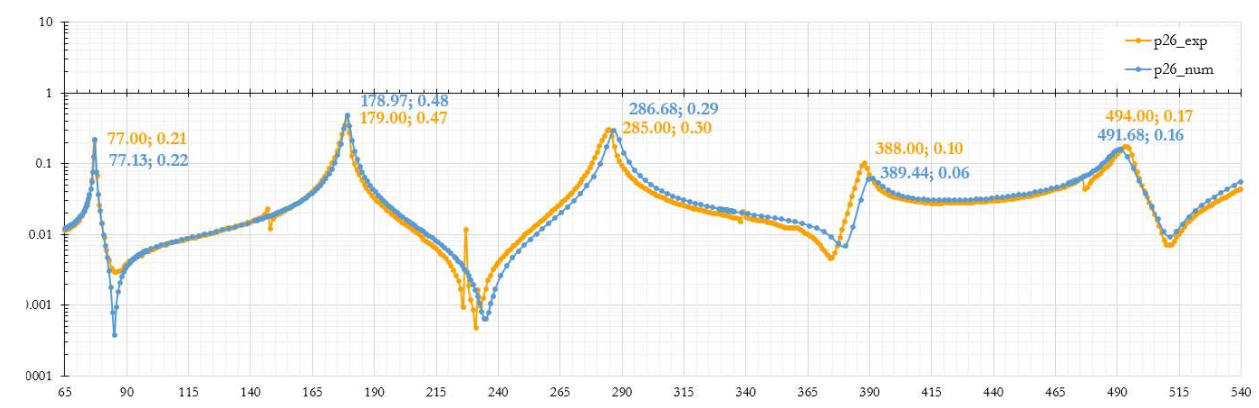

Fig. 6. FRFs for selected points: a) number 2; b) number 26

Table 6. Ultimate values of identification criterion
$\mathrm{S}_{\mathrm{I}}$
3.27E-4
$\mathrm{S}_{\text {II }}$
$2.56 \mathrm{E}-4$
$\mathrm{S}_{\mathrm{I}}+\mathrm{S}_{\mathrm{II}}$
5.83E-4 


\section{DAMAGE DIAGNOSTICS}

\subsection{Damage diagnostics algorithm}

DDL (Damage, Detection, Localization), our own original algorithm, was based on analysis of changes of dynamic parameters and wavelet transform. At this point, the algorithm was verified on the basis of identified discrete model of steelconcrete composite beams.

The algorithm was divided into two stages. First, damage detection, second damage localization. Detection was based on static and dynamic analysis of discrete model and its comparison with results obtained with undamaged discrete model. The analyzed parameters included frequency of natural vibration, forms of natural vibration, acceleration amplitudes, damping coefficient and static parameters (i.e. deflection, strain). An assumption was made that for the sake of analysis, an error of $10 \%$ between discrete model results may denote local damage. The absolute error was given by

$$
\Delta \mathrm{X}_{i}=\left|\frac{X_{i, n u}-X_{i, u}}{X_{i, n u}}\right| \cdot 100 \%
$$

where $X_{i, n u}=$ parameters of undamaged model, $X_{i, u}=$ parameters of damaged model.

The algorithm was verified on the basis of analysis conducted on two discrete models, i.e. for free-ends beam and for simply supported beam. The present paper discusses the results of the free-ends beam. Analysis was conducted using Abaqus computational solvers.

Damage localization was based on discrete wavelet transform (DWT). The difference between discrete wavelet transform of the damaged and undamaged system for each successive point of the signal was given in a generalized form

$$
\Delta D W T(a, b ; f(t), \psi(t))=\left|D W T_{n u}\left(a, b, f_{n u}(t)\right)-D W T_{u}\left(a, b, f_{u}(t)\right)\right| \cdot 100 \%
$$

where: $D W T_{n u(a, b)}=$ discrete transform of undamaged system signal; $\quad D W T_{u(a, b)}$ $=$ discrete transform of damaged system signal.

For clarity purposes, the difference between transforms was normalized in a scale from 0 to 1 , relative to the highest value of the transformed signal. Values close to 1 suggest it may be the location of damage.

\subsection{Damage definition for composite beams}

Damage is introduced into the model to verify our own, original algorithms of damage detection. Three types of damage were pre-defined. U1 - first type of damage - is damage of the bottom flange of the steel section. Damage was 
achieved by reducing the modulus of longitudinal elasticity in the steel beam, 2.4 $\mathrm{m}$ away from the head of the beam. $50 \%$ reduction was pre-set in a selected element. A schematic of the beam with damage is shown in Figure 7.

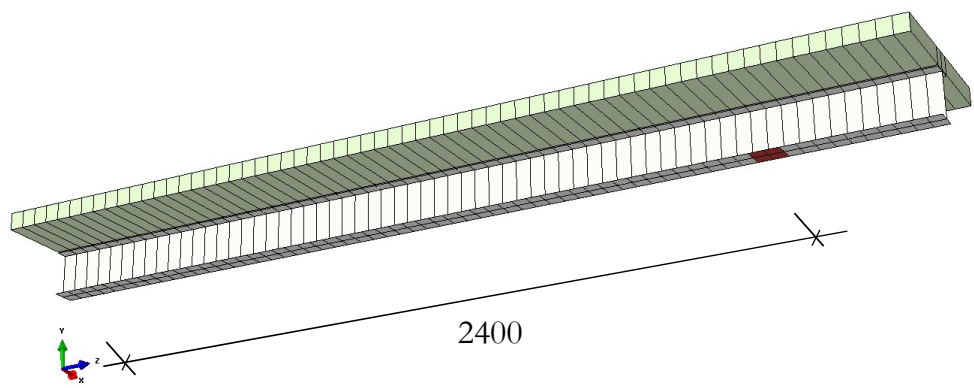

Fig. 7. Schematic of U1 type of damage

Diagnostics was performed next for composite beams with damaged concrete slab. U2 - second type of damage - was introduced by reducing the substitute dynamic modulus of longitudinal elasticity by $10 \%, 2.05 \mathrm{~m}$ away from the edge of the beam. A schematic of the beam with damage is shown in Figure 8. U3 third type of damage - was damage of the connection. The pre-defined assumption was that the third and fourth pairs of steel bolts counting from the edge of the beam will be damaged.

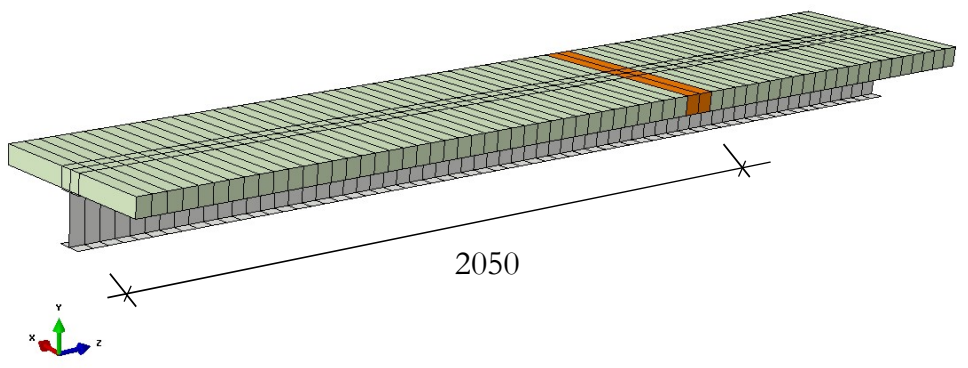

Fig. 8. Schematic of U2 type of damage

\subsection{Results of damage localization of composite beams}

Results of damage detection and localization divided according to those obtained with models with and without damage are shown in Tables 7-9.

Detection results show changes in the fundamental parameters of the model, i.e. frequency of natural vibration, vector of natural vibration forms, displacement amplitude and damping error. The damping coefficient was estimated based on calculated resistance of the model using Half Power Bandwidth method. Changes 
were defined by determination of the maximum error according to Equation (5.1) for successive parameter values.

Figure 9 shows changes in the vectors of natural vibration for the third (U1 and U2) and the four (U3) flexural form. Figure 10 shows changes in model resistance.

Table 7. Detection stage results, U1 type of damage

\begin{tabular}{|c|c|c|c|c|}
\hline $\begin{array}{l}\text { No./form } \\
\text { of vibration }\end{array}$ & $X_{i, n u}$ & $X_{i, u}$ & $\Delta X_{i}$ & $\begin{array}{l}\text { Damage } \\
\text { detection }\end{array}$ \\
\hline$\underline{1 . F r e q u e n c y}$ & $\mathrm{~Hz}$ & $\mathrm{~Hz}$ & $\%$ & \\
\hline $1 \mathrm{Gv}$ & 77.25 & 76.98 & 0.34 & $\mathrm{NO}$ \\
\hline $2 \mathrm{Gv}$ & 177.91 & 175.88 & 1.14 & $\mathrm{NO}$ \\
\hline $3 \mathrm{Gv}$ & 284.38 & 280.34 & 1.42 & NO \\
\hline $4 \mathrm{Gv}$ & 386.55 & 383.02 & 0.91 & $\mathrm{NO}$ \\
\hline $5 \mathrm{Gv}$ & 488.80 & 487.12 & 0.34 & $\mathrm{NO}$ \\
\hline 2.Form & - & - & $\%$ & \\
\hline $3 \mathrm{Gv}$ & 0.085 & 0.118 & 38.45 & YES \\
\hline $\begin{array}{l}\text { 3.Amplitude } \\
\text { of displacements }\end{array}$ & $\mathrm{m} / \mathrm{s}^{2} / \mathrm{N}$ & $\mathrm{m} / \mathrm{s}^{2} / \mathrm{N}$ & $\%$ & \\
\hline $1 \mathrm{GV}$ & 0.12 & 0.13 & 8.79 & NO \\
\hline $2 \mathrm{Gv}$ & 0.39 & 0.42 & 7.23 & $\mathrm{NO}$ \\
\hline $3 \mathrm{Gv}$ & 0.25 & 0.25 & 1.31 & NO \\
\hline $4 \mathrm{Gv}$ & 0.12 & 0.13 & 8.79 & $\mathrm{NO}$ \\
\hline $5 \mathrm{Gv}$ & 0.07 & 0.07 & 3.18 & $\mathrm{NO}$ \\
\hline 4.Damping & & & & \\
\hline coefficient & $\%$ & $\%$ & $\%$ & \\
\hline $1 \mathrm{Gv}$ & 0.71 & 0.73 & 1.85 & NO \\
\hline $2 \mathrm{Gv}$ & 0.64 & 0.99 & 55.54 & YES \\
\hline $3 \mathrm{Gv}$ & 0.84 & 0.74 & 11.73 & YES \\
\hline $4 \mathrm{Gv}$ & 0.66 & 0.70 & 5.54 & $\mathrm{NO}$ \\
\hline $5 \mathrm{Gv}$ & 0.89 & 0.98 & 9.08 & $\mathrm{NO}$ \\
\hline
\end{tabular}

Table 8. Detection stage results, U2 type of damage

\begin{tabular}{cllll}
$\begin{array}{l}\text { No./form } \\
\text { of vibration }\end{array}$ & $X_{i, n u}$ & $X_{i, u}$ & $\Delta X_{i}$ & $\begin{array}{l}\text { Damage } \\
\text { detection }\end{array}$ \\
\hline 1.Frequency & $\mathrm{Hz}$ & $\mathrm{Hz}$ & $\%$ & \\
\hline $1 \mathrm{Gv}$ & 77.25 & 76.93 & 0.41 & NO \\
$2 \mathrm{Gv}$ & 177.91 & 176.11 & 1.01 & NO \\
$3 \mathrm{Gv}$ & 284.38 & 280.14 & 1.49 & NO \\
$4 \mathrm{Gv}$ & 386.55 & 381.72 & 1.25 & NO \\
$5 \mathrm{Gv}$ & 488.8 & 485.21 & 0.73 & NO \\
\hline 2.Form & - & - & $\%$ & \\
\hline $3 \mathrm{Gv}$ & 0.096 & 0.139 & 44.74 & YES
\end{tabular}


3.Amplitude

of displacements $\mathrm{m} / \mathrm{s}^{2} / \mathrm{N}$

$\mathrm{m} / \mathrm{s}^{2} / \mathrm{N}$

$\%$

$\begin{array}{lllll}1 \mathrm{Gv} & 0.121 & 0.123 & 1.29 & \text { NO } \\ 2 \mathrm{Gv} & 0.390 & 0.387 & 0.87 & \text { NO } \\ 3 \mathrm{Gv} & 0.251 & 0.251 & 0.00 & \text { NO } \\ 4 \mathrm{Gv} & 0.121 & 0.123 & 1.29 & \text { NO } \\ 5 \mathrm{Gv} & 0.070 & 0.061 & 12.83 & \text { YES }\end{array}$

4.Damping

coefficient

$\begin{array}{cllll}\text { fficient } & \% & \% & \% & \\ 1 \mathrm{Gv} & 0.71 & 0.74 & 3.86 & \text { NO } \\ 2 \mathrm{Gv} & 0.64 & 0.90 & 40.83 & \text { YES } \\ 3 \mathrm{Gv} & 0.84 & 0.82 & 2.53 & \text { NO } \\ 4 \mathrm{Gv} & 0.66 & 0.64 & 2.70 & \text { NO } \\ 5 \mathrm{Gv} & 0.89 & 0.90 & 0.30 & \text { NO }\end{array}$

Table 9. Detection stage results, U3 type of damage

\begin{tabular}{|c|c|c|c|c|}
\hline $\begin{array}{l}\text { No./form } \\
\text { of vibration }\end{array}$ & $X_{i, n u}$ & $X_{i, u}$ & $\Delta X_{i}$ & $\begin{array}{l}\text { Damage } \\
\text { detection }\end{array}$ \\
\hline 1.Frequency & $\mathrm{Hz}$ & $\mathrm{Hz}$ & $\%$ & \\
\hline $1 \mathrm{Gv}$ & 77.25 & 76.61 & 0.83 & $\mathrm{NO}$ \\
\hline $2 \mathrm{Gv}$ & 177.91 & 175.65 & 1.27 & NO \\
\hline $3 \mathrm{Gv}$ & 284.38 & 279.24 & 1.81 & NO \\
\hline $4 \mathrm{Gv}$ & 386.55 & 370.70 & 4.10 & NO \\
\hline $5 \mathrm{Gv}$ & 488.8 & 464.67 & 4.94 & NO \\
\hline 2.Form & - & - & $\%$ & \\
\hline $3 \mathrm{Gv}$ & -0.193 & -0.024 & 87.75 & YES \\
\hline 3.Amplitude & & & & \\
\hline of displacements & $\mathrm{m} / \mathrm{s}^{2} / \mathrm{N}$ & $\mathrm{m} / \mathrm{s}^{2} / \mathrm{N}$ & $\%$ & \\
\hline $1 \mathrm{Gv}$ & 0.121 & 0.140 & 15.24 & YES \\
\hline $2 \mathrm{Gv}$ & 0.390 & 0.412 & 5.51 & NO \\
\hline $3 \mathrm{Gv}$ & 0.251 & 0.264 & 5.18 & NO \\
\hline $4 \mathrm{Gv}$ & 0.121 & 0.140 & 15.24 & YES \\
\hline $5 \mathrm{Gv}$ & 0.070 & 0.164 & 133.33 & YES \\
\hline 4.Damping & & & & \\
\hline coefficient & $\%$ & $\%$ & $\%$ & \\
\hline $1 \mathrm{Gv}$ & 0.71 & 0.63 & 10.89 & YES \\
\hline $2 \mathrm{Gv}$ & 0.64 & 1.00 & 56.52 & YES \\
\hline $3 \mathrm{Gv}$ & 0.84 & 0.84 & 0.19 & $\mathrm{NO}$ \\
\hline $4 \mathrm{Gv}$ & 0.66 & 0.68 & 3.08 & NO \\
\hline $5 \mathrm{Gv}$ & 0.89 & 0.76 & 14.81 & YES \\
\hline
\end{tabular}


a)

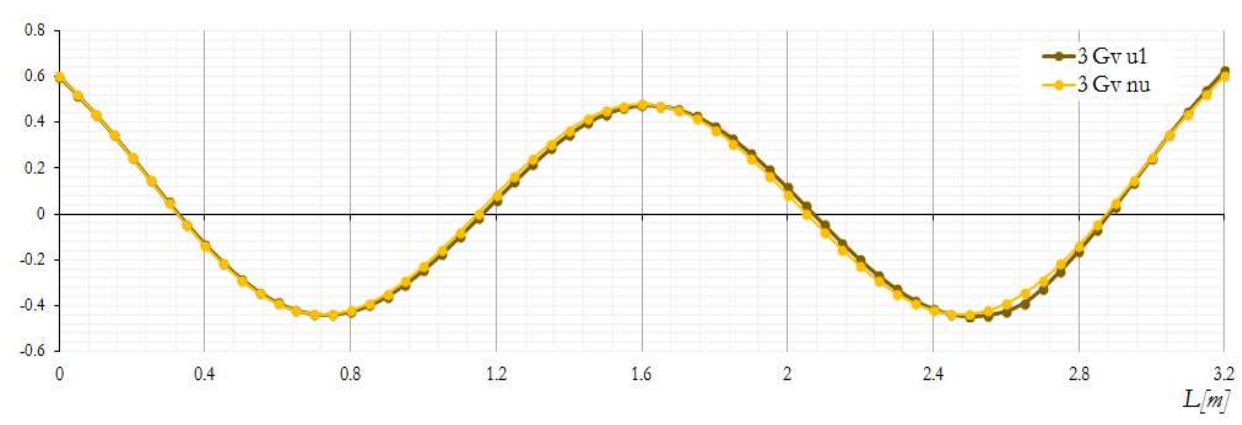

b)

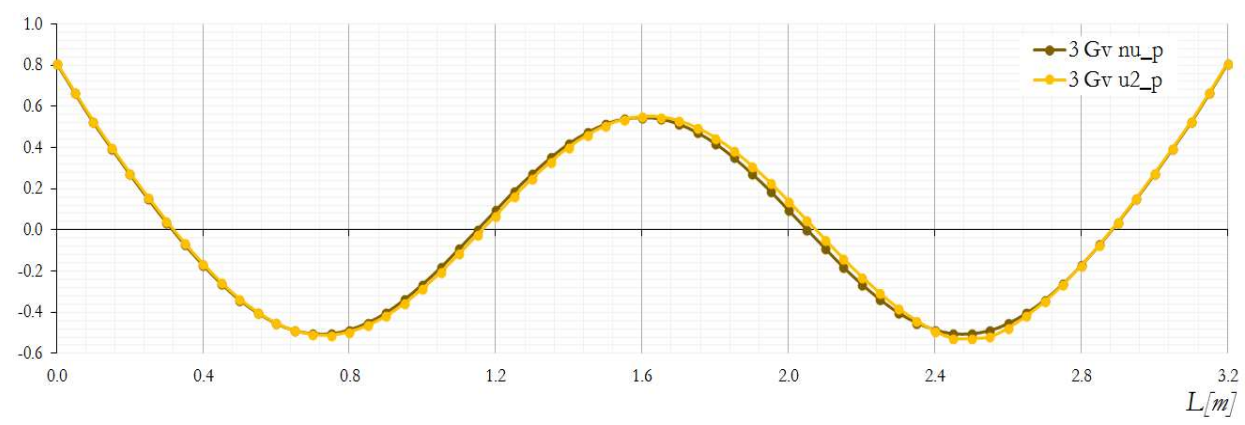

c)

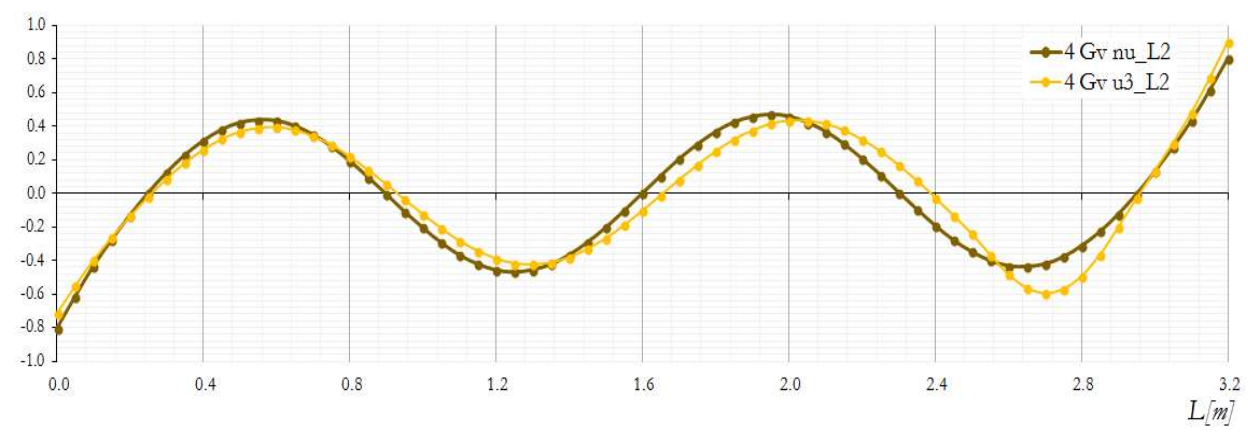

Fig. 9. Vibration vectors: a) third form of U1 vibration, b) third form of U2 vibration, fourth form of $\mathrm{U} 3$ vibration 
a)

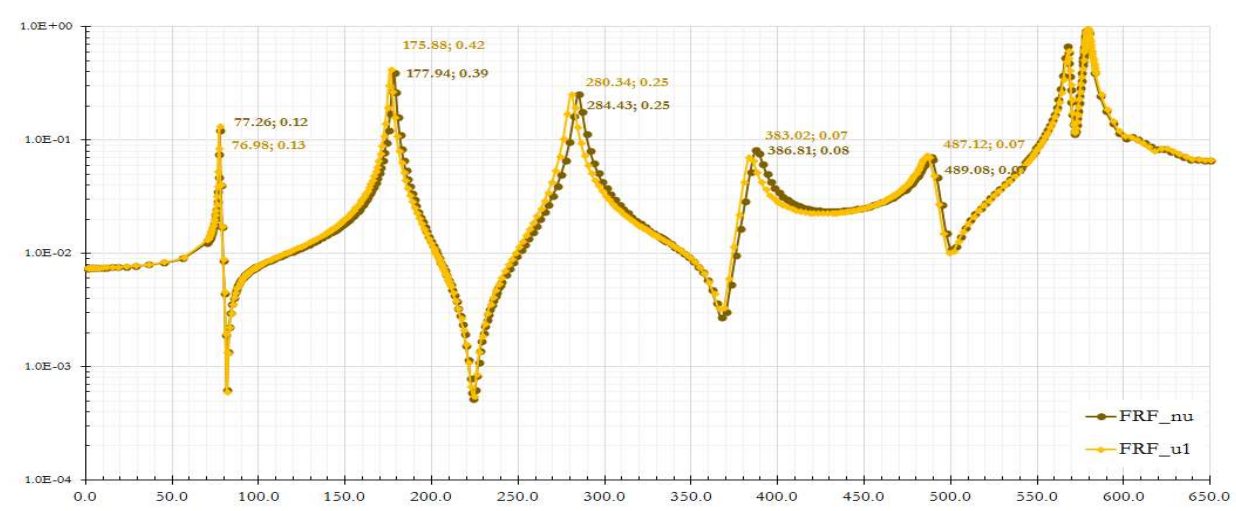

b)

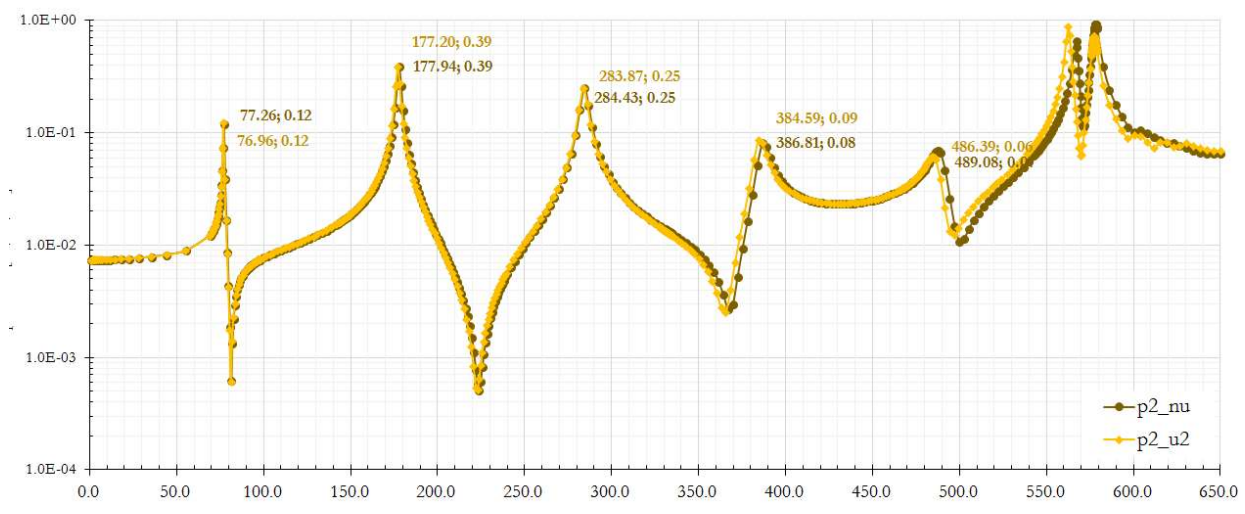

c)

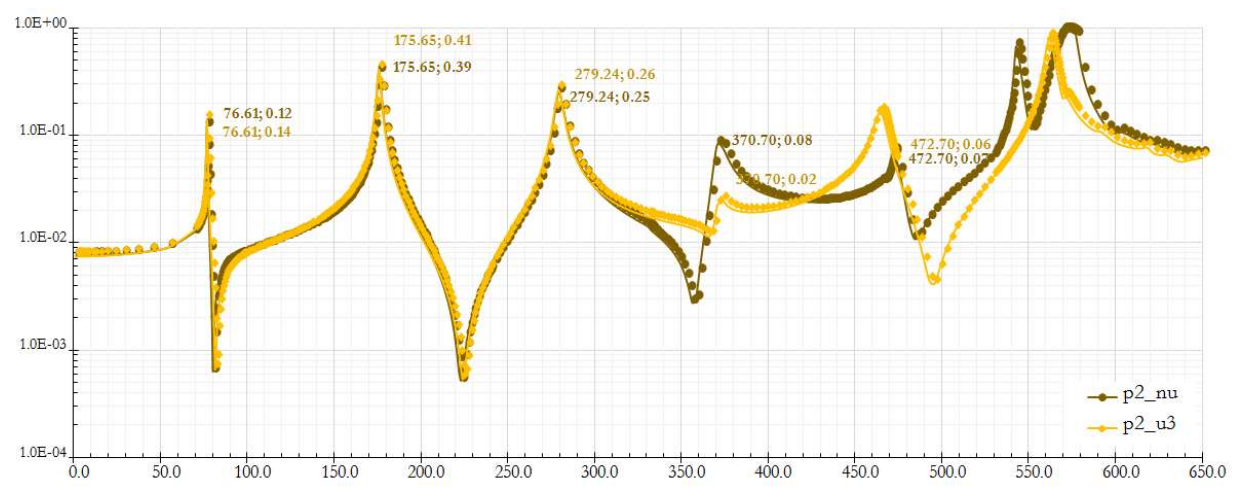

Fig. 10. Changes in resistance of models: a) $U 1$, b) $U 2$, c) U3. 
Figure 11 shows results of damage localization as normalized vector of transform errors, relative to decomposition details of five forms of flexural vibrations.

a)

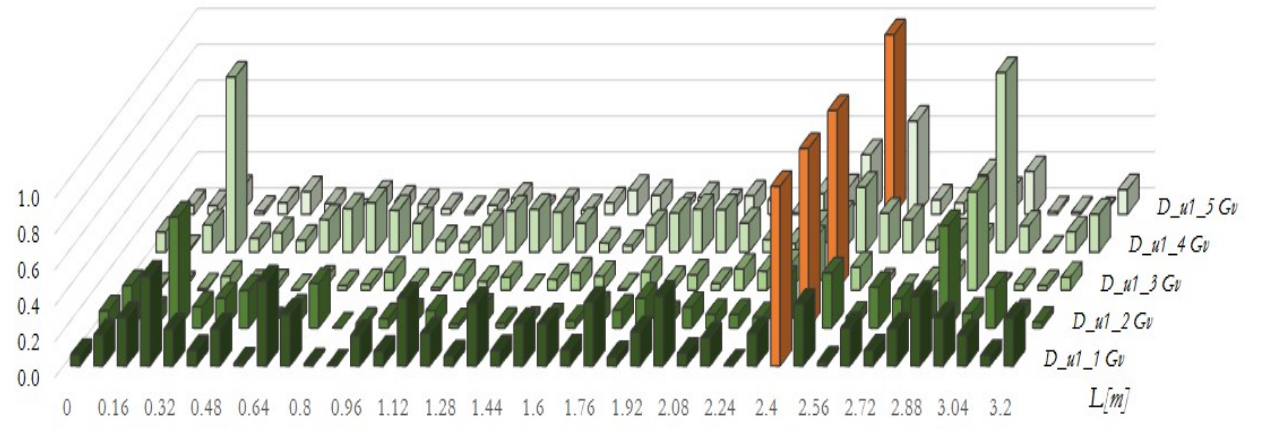

b)

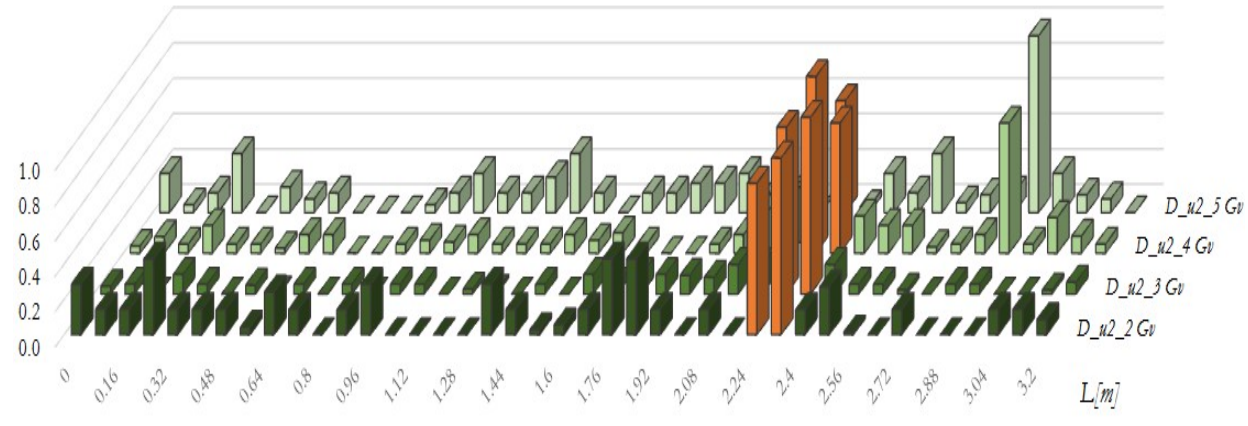

c)

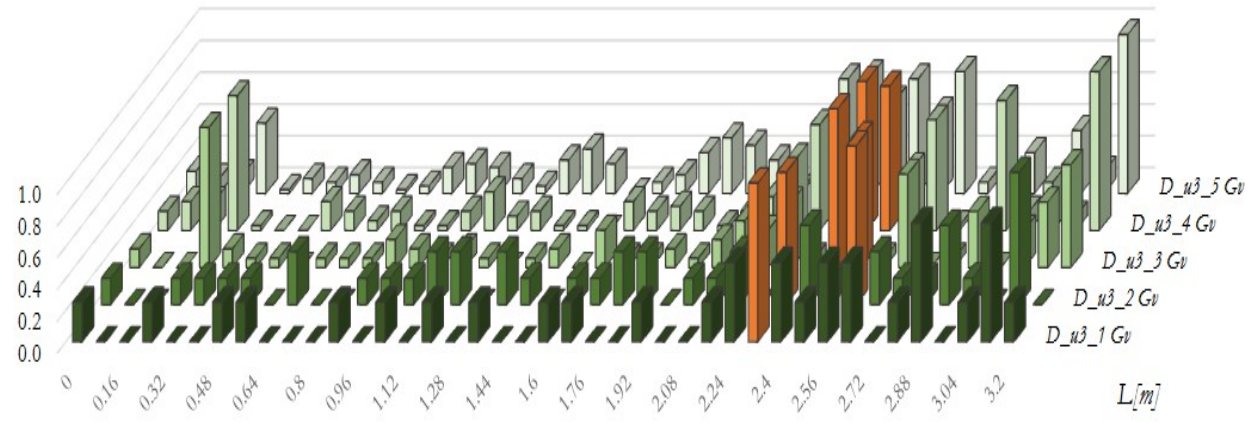

Fig. 11. Results of damage localization for damage type: a) U1, b) U2, c) U3. 


\section{CONCLUSIONS}

The aim of this paper was to conduct static-dynamic analysis of steel-concrete composite beams and to attempt to detect damage of a discrete model. Prior to damage diagnostics, a two-tier process of identifying static-dynamic parameters of the discrete model based on experimental data was conducted. This necessary process is about fitting parameters of a model using experimental data. The results of parameter identification show that results obtained with the original discrete models are consistent with those obtained in the experiment. Advanced tools were used for modeling (Python), computations (Abaqus) and optimization (Matlab), which significantly facilitated the tuning of the discrete models. The originally developed identification algorithm can be used not only for the tuning of discrete models of composite beams, but also for other civil engineering components with simple or complex structure.

Analysis of damage detection was conducted based on the originally developed algorithm. Wavelet analysis was used. Changes in dynamic parameters of damaged model were compared with those of undamaged model.

Not all methods used for detection were successful. This stage of diagnostics only signals about changes in the response of a system. DWT that used several signals obtained in dynamic analysis could quite precisely locate damage. This confirms the possibility of using DWT for diagnostics of composite beams. Disturbances at graph ends result from analysis of the signal conducted with wavelet transform. In order to eliminate disturbances, some scientists, e.g. [10], extrapolate the signal which can get rid of disturbances. Interestingly, the disturbances also had an effect on the results produced by the program. However, analysis of several DWT signals can verify disturbances caused by failure to apply extrapolation.

Further analysis is necessary on the effect of measurement mesh density and distance between damage and the line of points on detection results. At this point, the diagnostics algorithm is extended to include experimental data about steelconcrete composite beams.

\section{REFERENCES}

1. Uhl T.: Mechatronics In Diagnostics; Diagnostyka, 3(47), Publisher 2008, 143-152.

2. Rucka M.: Neuro-Wavelet damage detection technique in beam, plate and shell structures with experimental validation, Journal of Theoretical and Applied Mechanics 48, 3 (2010) 579-604.

3. Białasiewicz J. T.: Falki I aproksymacje; Wydawnictwo NaukowoTechniczne, ISBN 83-204-2971-4, Warszawa, Publisher 2004. 
4. Doebling S., Farrar, C., Prime, M., and Shevits, D.: Damage identification and health monitoring of structural and mechanical systems from changes in their vibration characteristics: A literature review; Los Alamos National Laboratory, USA,1, Publisher 1996, 1-136.

5. Wilde, K.: Możliwości zastosowania systemów monitoringu technicznego $w$ infrastrukturze elektroenergetycznej, Acta Energetica, 2 (2009) 107:114.

6. Knitter-Piatkowska A., Garstecki A.: Wavelet transformation in damage identification by dynamic tests; PAMM 4,1 , (2004) 404-405.

7. Knitter-Piątkowska A., Pozorski Z., Garstecki A.: Application of discrete wavelet transformation in damage detection. Part I: Static and dynamic experiments; Computer Assisted Mechanics and Engineering Sciences 13 (2006) 21-38.

8. Salawu, O.: Detection of structural damage through changes in frequency: a review. Engineering Structures, 19,9 (1997) 718-723.

9. Marcinowski J.: Detection of structural heterogeneities by the wavelet technique, International Journal of Applied Mechanics and Engineering. 12, 2 (2007) 487-495, ISSN: 1425-1655.

10. Chung-Jen $\mathrm{Lu}$ and $\mathrm{Yu}-\mathrm{T}$ sun Hsu.: Application of wavelet transform to structural damage detection; Department of Mechanical Engineering National Taiwan University Taipei, Taiwan, Republic of China, Publisher 2002.

11. Rucka M. Wilde K.: Damage location in beam and plate structures by wavelet analysis of experimentally determined mode shapes. Key Engineering Materials; 293-294 (2005) 313-320.

12. Ziopaja K., Pozorski Z. Garstecki A.: Application of discrete wavelet transformation in damage detection. Part II: Heat transfer experiments, Computer Assisted Mechanics and Engineering Sciences 13 (2006) 21-38.

13. Kucharczuk W., Labocha S.: Konstrukcje zespolone stalowo-betonowe budynków. Arkady, Warszawa, Publisher 2007.

14. Queiroz F.D., Vellasco P.C.G.S.: Nethercot D.A.: Finite element modelling of composite beams with full and partial shear connection. J. of Constructional Steel Research, 63, 4 (2007) 505-521.

15. Jankowiak I., Madaj A.: Analiza numeryczna wzmocnienia taśmami CFPR betonu rozciaganego stalowo-betonowej belki zespolonej; X Konferencja Naukowa Konstrukcje Zespolone, Zielona Góra (2014), 217-232.

16. Polus Ł., Szumigała M.: Analiza numeryczna nośności i sztywności belki zespolonej aluminiowo-betonowej; X Konferencja Naukowa Konstrukcje Zespolone, Zielona Góra (2014) 393-405. 
17. Szewczyk P., Szumigała M.: Analiza numeryczna wzmacniania belki zespolonej; X Konferencja Naukowa Konstrukcje Zespolone, Zielona Góra (2014) 217-232.

18. Berczyński S., Wróblewski T.: Experimental Verification of Natural Vibration Models of Steel-concrete Composite beams. J. of Vibration and Control, 16 (2010) 2057-2081.

19. Oberkampf, W. L. Blottner F. G.: Issues in Computational Fluid Dynamics Code Verification and Validation, AIAA Journal, 36,5 (1998) 687-695.

20. Oberkampf, W. L., T. G. Trucano, and C. Hirsch.: Verification, Validation, and Predictive Capability, Applied Mechanics Reviews, (2004) 2003-3769.

\section{DIAGNOSTYKA USZKODZEŃ STALOWO-BETONOWYCH BELEK ZESPOLONYCH}

\section{Streszczenie}

Niniejszy artykuł przedstawia wyniki analiz stalowo-betonowych belek zespolonych, identyfikację oraz próby detekcji uszkodzeń wprowadzonych w modelu dyskretnym. Analizy detekcji uszkodzeń przeprowadzono na podstawie opracowanego algorytmu UDL (Uszkodzenia D-detekcja, L-Lokalizacja). Podczas diagnostyki uszkodzeń analizowano zmiany w parametrach dynamicznych i statycznych modelu. Podczas lokalizacji uszkodzeń modelu wykorzystano dyskretną transformatę falkową. Analizy docelowe zostały poprzedzone dwupoziomowym procesem identyfikacji wybranych parametrów modelu dyskretnego w oparciu o wyniki badań doświadczalnych. Procedury identyfikacji przeprowadzono łącząc programy obliczeniowe (Python, Abaqus, Matlab) w automatyczne pętle optymalizacyjne. Wyniki przeprowadzonych analiz pozytywnie weryfikują opracowany algorytm UD-L do diagnostyki uszkodzeń stalowo-betonowych belek zespolonych, co pozwala na dalsze analizy w oparciu o badania doświadczalne.

Słowa kluczowe: stalowo-betonowe belki zespolone, uszkodzenia, detekcja, uszkodzenia, Python, Abaqus, Matlab

Editor received the manuscript: 10.09.2017 